\title{
Comparison of Total Suspended Particulate (TSP) Measurement in Urban and Suburban Areas of Bali during Nyepi Day 2015
}

\author{
Tri A. Nuraini ${ }^{*}$, Ratna Satyaningsih ${ }^{1}$, Donaldi S. Permana ${ }^{1 *}$, Rian Anggraeni ${ }^{1}$, Edvin Aldrian ${ }^{2}$ \\ ${ }^{1}$ Center for Research and Development, Indonesian Agency for Meteorology Climatology and \\ Geophysics, Jl. Angkasa 1 No 2, Kemayoran, Jakarta 10720, Indonesia \\ ${ }^{2}$ Agency for the Assessment and Application of Technology, Jl.MH.Thamrin 8, Jakarta 10340, \\ Indonesia \\ *) Corresponding Author (astuti.nuraini@bmkg.go.id; donaldi.permana@bmkg.go.id)
}

Received: 20 Agustus 2019 / Accepted: 28 Desember 2019 / Published: 11 Januari 2020

\begin{abstract}
Nyepi, or the Balinese Day of Silence (DOS), is the day when people celebrate the New Year according to the Balinese calendar (Saka). On that day, all resident activities are very restricted, with no outdoor activities. This event, which only lasts for 24 hours, is a unique period in which to evaluate air quality, for example through the measurement of Total Suspended Particulate (TSP), to assess the influence of human activities. This study only focuses on TSP monitoring before, during and after DOS and its comparison with the meteorological data. TSP concentration measurements were conducted in two urban areas (Badung and Ubung) and a suburban area (Singaraja) from March 17 to March 25, 2015. The results show that TSP concentrations are negatively correlated with temperature and wind speed in each location. Hourly TSP concentrations during DOS are lower than the average TSP concentrations before and after DOS. During DOS, TSP concentrations decreased significantly in urban areas by $73-78 \%$ relative to regular days, which is likely due to the drastic decrease in human activities. In suburban areas, the decrease in TSP concentration was about 59\%. These results show that human activities highly influence the air quality.
\end{abstract}

Keywords: Total Suspended Particulate, Bali, Nyepi Day

Abstrak. Hari Raya Nyepi merupakan perayaan tahun baru Hindu berdasarkan penanggalan Saka. Pada saat Nyepi, semua aktivitas penduduk di luar rumah berhenti. Momentum ini hanya terjadi selama 24 jam dalam kurun wakti 1 tahun sehingga sangat baik digunakan untuk melakukan pengukuran kualitas udara seperti parameter debu total (TSP) untuk mengetahui pengaruh aktivitas manusia. Lokasi. Penelitian difokuskan melakukan pengukuran TSP sebelum, pada saat, dan setelah Nyepi serta dibandingkan dengan data meteorologi. Pengukuran konsentrasi TSP dilakukan di 2 lokasi daerah perkotaan (Badung dan Ubung) dan sub perkotaan (Singaraja) mulai tanggal 17 sampai dengan 25 maret 2015. Hasil penelitian menunjukkan bahwa konsentrasi TSP berkorelasi negarif dengan temperatur dan kecepatan angin pada setiap lokasi. Konsentrasi TSP perjam selama Nyepi lebih rendah dibandingkan dengan rata-rata konsentrasi sebelum dan sesudah Nyepi. Selama Nyepi, konsentrasi TSP mengalami penurunan secara signifikan pada daerah perkotaan berkisar antara $73-78 \%$ secara relatif dibandingkan dengan hari biasa yang kemungkinan disebabkan penurunan aktivitas manusia secara drastis. Pada daerah sub perkotaan, penurunan konsentrasi TSP sekitar 59\%. Hasil ini menunjukkan bahwa tingginya aktifitas manusia berpengaruh terhadap kualitas udara.

Kata kunci: Debu Total, Bali, Nyepi 


\section{Introduction}

According to Law No. 32 on Protection and Environment Management, 2009, air pollution refers to human-induced pollution that is caused by activities such as industrial processes, motor vehicle exhausts, incinerators, and agricultural waste, and to pollution caused by natural events such as wildfires and volcanic eruptions that produce volcanic material, and clouds of hot ash and gas. Government Regulation No. 41 defined air pollution as the diffusion (either naturally or unnaturally) of substances, energy, and/or other components to ambient air due to human activity so that the ambient air quality declines to a certain level at which it can no longer function properly. While both regulations have explicitly mentioned that human activities cause air pollution, Wardhana (1994) simply defines air pollution as substances in the atmosphere that cause changes in the atmospheric composition. According to Oke (1987), the amount of pollution at a site is determined by two factors; they are (1) the nature of relevant emission, and (2) the state of the atmosphere. Natural causes of air pollution include windblown dust, ash spilled from volcanic eruptions, and gas released from volcanic eruptions and waste decomposition (Sugiarti, 2009).

The increased concentration of air pollutants has caused serious problems in some regions of Indonesia. These problems include disruption to human health, visibility reduction and decreased air quality in urban areas, affecting the radiation balance in the atmosphere (Aldrian et al., 2014). The airborne particulate matter (PM), as one form of air pollution, has particularly been associated with adverse health impacts on urban populations in both developed and developing countries (WHO, 2006). As reported by the WHO Global Burden of Disease project, the urban air pollution worldwide, as measured by concentrations of $\mathrm{PM}$, is responsible for about $5 \%$ of all mortality, which is attributable to health issues such as cancers of the lung, trachea, and bronchus (Cohen et al., 2005).

Based on its aerodynamic diameter, PM can be classified into $\mathrm{PM}_{1.0^{\prime}} \mathrm{PM}_{2.5^{\prime}} \mathrm{PM}_{10^{\prime}}$ and total suspended particulates(TSP), with corresponding diameters of less than 1.0, 2.5, 10, and $100 \mu \mathrm{m}$, respectively (Liu et al., 2014). TSPs can exist in the form of liquid droplets or solid particles such as smoke, dust, and mist. The three major characteristics of particulate pollutants in the ambient atmosphere are total mass concentration, chemical composition, and size distribution. In the ambient air, the size distribution of TSPs is a tri-modal type, including ultrafine particles, fine particles, and coarse particles. Fine particles are derived mostly from the direct emissions of combustion processes, such as wood-burning, vehicle use of diesel and gasoline, coal-burning from power generation, and industrial processes, such as cement plants, paper mills, steel mills, and smelters. Coarse particles are derived mostly from the suspension or resuspension of soil, dust, or other crustal material from volcanoes, windstorms, roads, mining, farming, and so forth (Pope and Dorkey, 2006).

Particulates suspended in the atmosphere are naturally removed through deposition by rain and transport, by wind or other atmospheric instability. However, because the number of particulates emitted to the atmosphere is increasing, the atmosphere's natural ability to remove this pollutant is decreasing. As a result, air pollution concentration tends to increase, with negative consequences. The spread of particulate emissions to the surroundings of their source depends on four factors; these are (1) properties of the emission, (2) effect of the earth's surface, (3) parameters of the source (variability in time, height above ground, temperature, capacity, and output speed of emission), and (4) meteorological factors (Hrdličková et al., 2008). The main meteorological factors that affect air pollution dispersion are wind speed, wind direction, and atmospheric turbulence or stability (Colls, 2002). Meanwhile, in desert landforms, the amount of TSP emission is predominantly controlled by surface characteristics and geomorphic setting (Bacon et al., 2011).

In addition, the decisive effect on the spread of pollutants is also influenced by the characteristics of the source including the shape of the emission area, the duration of the release, and the effective height at which the injection 
of pollutants occurs (Oke, 1987). Furthermore, human activity in a particular time period and location also determines the air pollution concentration. For example, a high concentration of air pollution during a long holiday is associated with the activities of people that tend to go on a trip outside the city, therefore causing an increase in traffic volume a day before and on the last day of the holiday (Aldrian et al., 2014). Another example of human activity affecting air pollution concentration is that in Beijing more than $70 \%$ of emissions are associated with the products consumed, and about $50 \%$ of TSP emissions are pollutions associated with non-metal mineral production and with electricity and heating supply (Yang et al., 2015).

Day of Silence (DOS), locally known as Nyepi, is New Year's Day according to the Balinese calendar (Saka). DOS lasts for 24 hours, starting at 6 AM local time. DOS is a day reserved for self-reflection, and as such, anything that might interfere with that purpose is highly restricted (Kasa, 2011). The main restrictions are no working, no entertainment or pleasure, no lighting fires (or lights must be kept low), no traveling, and for some people, no eating or talking at all. Even though Nyepi is a Balinese Hindu holiday, visitors and non-Hindu residents are not exempted from the above restrictions. As a result, during DOS streets and roads are dormant, few signs of human activity are seen even inside houses, and there is little or no noise from radios and televisions. The only people to be seen outdoors are the Pecalang, traditional security men who patrol the streets to ensure the above restrictions are being observed. Even though DOS is a Hindu holiday, all non-Hindu residents in Bali also observe DOS as a mark of respect for their fellow Hindu residents. Moreover, foreign tourists are not exempted; although they are free to do anything inside their own hotels, no one is allowed onto the streets or beaches, and even the only airport in Bali remains closed for the whole day. The only exceptions granted are emergency vehicles carrying women about to give birth or those with life-threatening conditions. On this day, Balinese do not leave their houses nor engage in any worldly or physical activities. As there are not any outdoor activities, the air quality in the Bali region is expected to be better than on usual days. Aprilina et al. (2016) conducted related research on air quality measurement on DOS for the parameters of Carbon Monoxide (CO) and temperature. The result showed that there was generally a positive linear relation between $\mathrm{CO}$ concentration and temperature in Denpasar, Bedugul, and Singaraja during DOS, whereas before and after DOS the relation between $\mathrm{CO}$ concentration and temperature appears inconsistent due to the influence of other factors, mainly caused by human activity (anthropogenic factors). This study aims to measure the TSP concentration before, during, and after DOS (March 21, 2015), in urban and suburban areas in Bali and to investigate the possible factors influencing the TSP concentrations.

\section{Research Method}

During the period of March 17-25, 2015, we monitored the TSP concentration using the HAZDUST EPAM-5000 instrument and collected meteorological data using a portable weather station (PWS) (Figure 1) in three locations on Bali Island (Figure 2). HAZ-DUST EPAM5000 provides a complete real-time profile and graphical representation of airborne particulate levels and exposures with data read out in milligrams per cubic meter $\left(\mathrm{mg} / \mathrm{mg}^{3}\right)$. This device is a high sensitivity real-time particulate monitor intended for indoor air quality and ambient environmental applications, and it is easy to set up in minutes to measure $\mathrm{PM}_{1.0^{\prime}} \mathrm{PM}_{2.5^{\prime}} \mathrm{PM}_{10^{\prime}}$ or TSP (EDC, 1999). The portable TSP monitoring instrument uses light scattering to measure airborne particle concentration. Two instruments were stationed in Badung and Ubung, which are urban areas close to Denpasar (the capital city of Bali) in the southern part of Bali. The third instrument was installed in the suburban area of Singaraja, which lies in the northern part of Bali. The instruments were set up close to the main road in Badung and Singaraja, while in Ubung the instrument was set up on the third floor of a building near the bus terminal. 


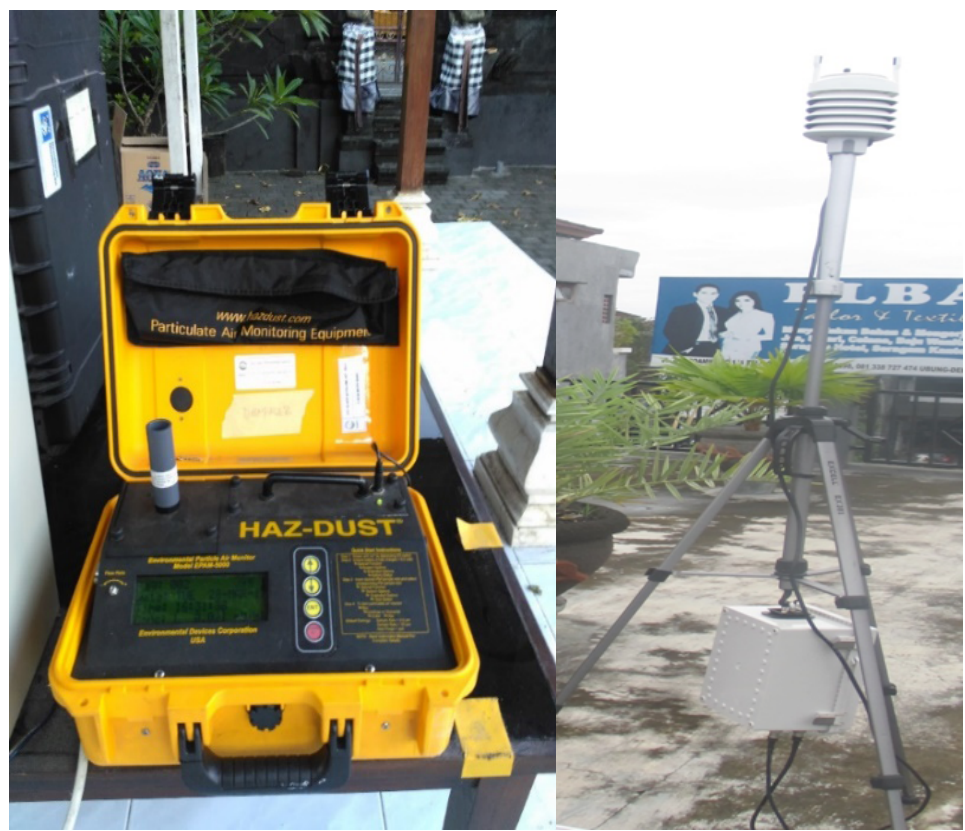

Figure 1. Instruments used in this study: (a) HAZ-DUST EPAM-5000 and (b) Portable Weather Station (PWS).

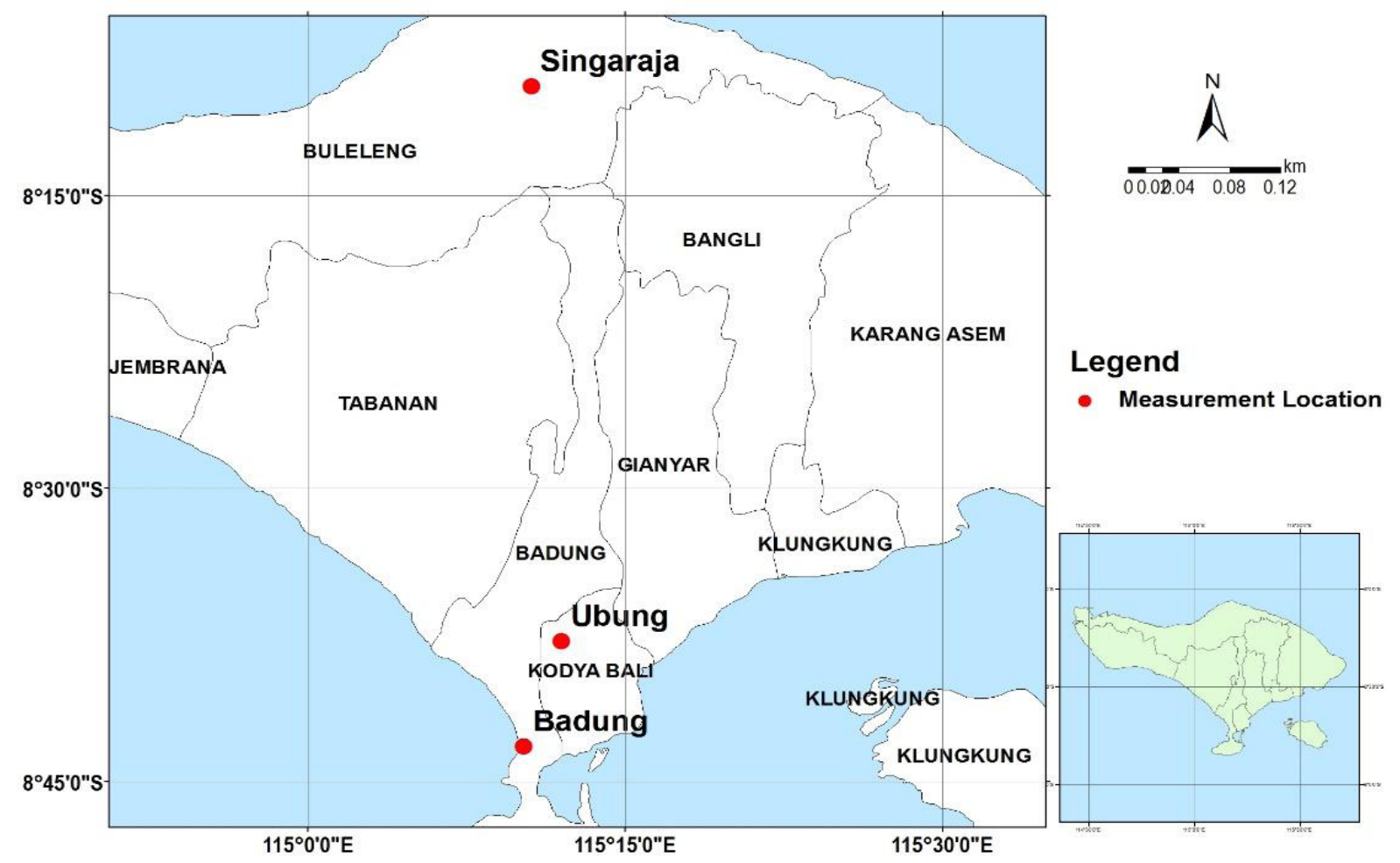

Figure 2. TSP monitoring sites (red points) during DOS 2015 in Denpasar (Badung and Ubung), and Bedugul (Singaraja). 

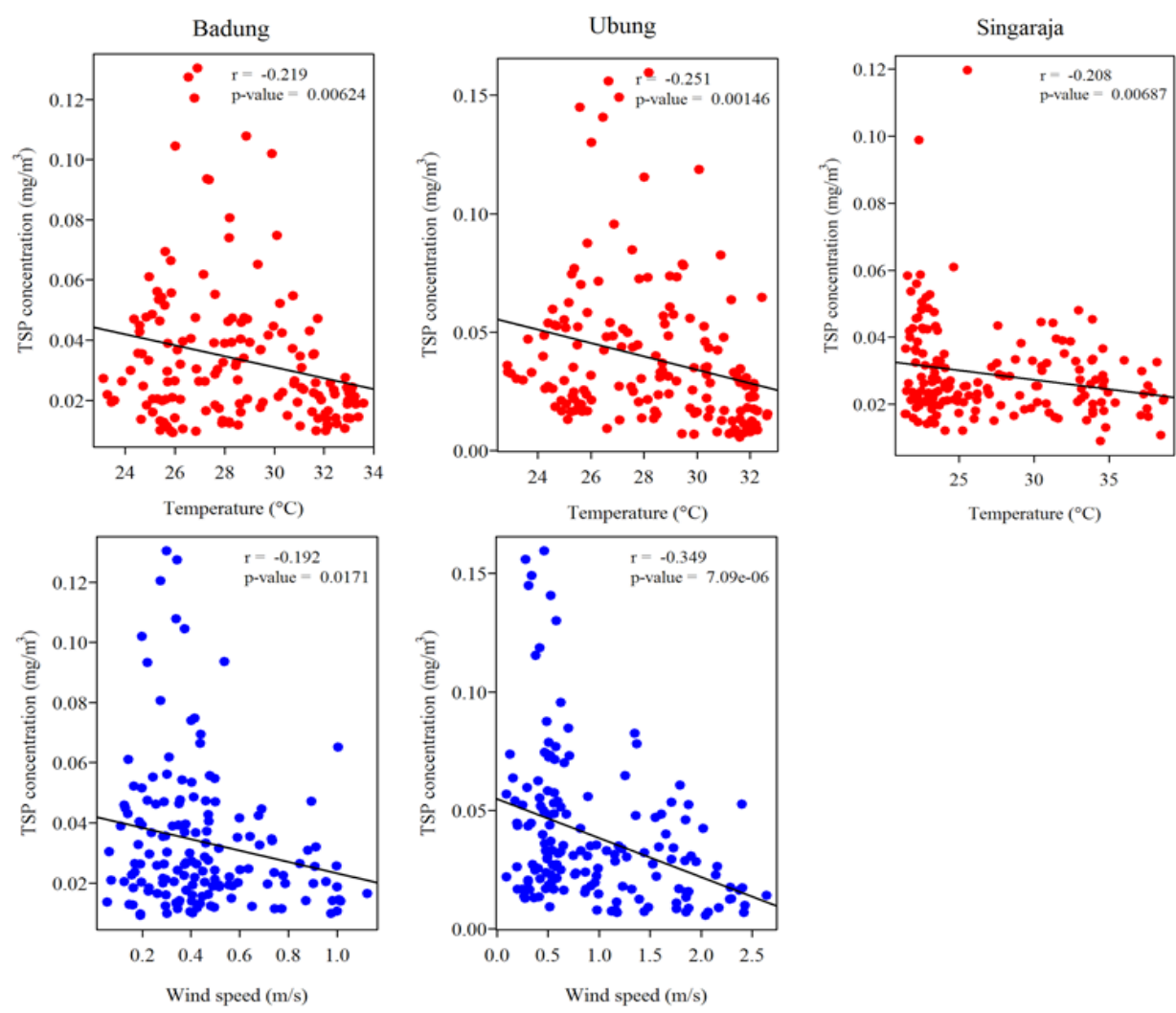

Figure 3. Correlations between TSP concentration and temperature (top panel), and wind speed (bottom panel) in Badung, Ubung, and Singaraja. (Wind speed in Singaraja was not measured during the observation period.)

TSP concentration data were recorded for every minute and meteorological data were collected for every 10 minutes. These were each then averaged into hourly data. Afterwards, hourly TSP concentration data were compared to wind speed and temperature at each location to investigate possible connections. We assumed that the minimum hourly TSP concentration during DOS serves as a nonanthropogenic background value for each location which represents the TSP concentration without human activities. Meanwhile, the hourly mean TSP concentrations of the 4 days before and 4 days after DOS serve as baseline values representing the concentration during regular days. The changes in the hourly TSP concentration during DOS ( 24 hours starting from $6 \mathrm{AM}$ ) were calculated relative to the baseline values using the formula given in Equation (1).

Relative change (\%) $=1-\frac{\sum(S-B g)}{\sum(B-B g)}$

where:

$B g=$ Non-anthropogenic background value

$B=$ Baseline value

$S=$ TSP concentration during DOS

\section{Results and Discussion}

Before analyzing the TSP concentration during DOS, we examined the correlation between the TSP concentration and the surface temperature and wind speed during the observation period, respectively. We also explored the diurnal pattern of TSP concentration. Figure 3 shows the comparison 
between hourly TSP concentration and meteorological parameters (temperature and wind speed) at each location during the observation period. There are significant negative correlations between TSP concentration and temperature with R-values of $-0.22,-0.25$ and -0.21 ( $p$-values $<0.01$ ) in Badung, Ubung, and Singaraja, respectively. These correlations are associated with a diurnal cycle of TSP concentration with higher TSP concentrations during the nighttime (cooler) and lower TSP concentrations during the daytime (warmer). The influence of temperature on TSP concentration is not straightforward but, instead, is indirect due to the atmospheric mixing layer changing between day and nighttime (Li et al., 1999; Turyanti, 2016; and Sheng, 2004).

From the morning to the afternoon, solar radiation warms the surface intensively and causes the air to expand. As a result, the atmospheric mixing layer increases and reaches a peak in the afternoon. This fluctuation follows the surface temperature pattern. Meanwhile, during the night, the surface temperature decreases, leading to the thinning of the atmospheric mixing layer with a peak at midnight to early morning. The fluctuation of the atmospheric mixing layer's thickness is indicative of the mixing of pollution into the air. During the daytime, intensive warming causes a broad distribution of pollution in the thicker mixing layer, leading to low pollution concentration at the surface. Conversely, during the night, the mixing layer is much thinner due to cooling air, and air pollution concentrations are potentially increased at the surface (Turyanti, 2016; Sheng, 2004). In addition, this temperature effect may also be related to the fact that precipitation events, which subsequently reduce dust formation due to wet deposition, are often associated with a decrease in the ambient air temperature before rain clouds are formed. Furthermore, TSP concentrations are also negatively correlated with wind speed in Badung $(\mathrm{r}=-0.2)$ and Ubung $(\mathrm{r}=$ -0.35) (see Figure 3). Unlike temperature, the influence of wind speed on TSP concentration is direct. Higher wind speeds tend to blow PM away from the locations and cause lower TSP concentrations, while lower wind speeds result in higher TSP concentrations. Note that wind speed in Singaraja was not measured during the observation period.

Hourly TSP concentrations for each day during the monitoring period are depicted in Figure 4 for all three sites. The diurnal cycle of TSP concentration is clearly observed in Badung and Ubung (Figures $4 \mathrm{a}$ and $4 \mathrm{~b}$ ), which represent the urban area. At both sites, TSP concentration begins to increase early in the morning and peaks at around 8 AM local time. This could be explained by human activities in the market and the bus terminal which usually start around this time. Afterwards, residents continue their activity in either their homes or workplaces. This then causes TSP concentration to decrease and it reaches its lowest concentration in the afternoon before it starts to increase again and peak at around midnight (9 PM-2 AM). It is very likely that the increase in TSP concentration in the late afternoon ( $5 \mathrm{PM})$ was due to high traffic when most people return home from work. The observed diurnal cycle of TSP concentration in these regions are typical of other urban areas, such as those observed in Hungary (Kiss et al., 2005) and Kenya (Mogere, 2002). On the other hand, the diurnal cycle of TSP concentration in Singaraja (Figure 4c) did not show a similar pattern to those observed in Badung and Ubung. This result suggests that PM often fluctuates over some periods of time where the concentrations increase throughout the day till midnight. Between $3 \mathrm{AM}$ and 8 $\mathrm{AM}$, the particulate concentrations are lower, possibly due to less or no human activities during this period (Alias et al., 2007). The diurnal fluctuation of TSP concentration in this site was relatively insignificant. This is due to the fact that the measurement was conducted in a suburban area and the instrument was not located near the main road, hence the volume of traffic was not as high as in the two other sites. 

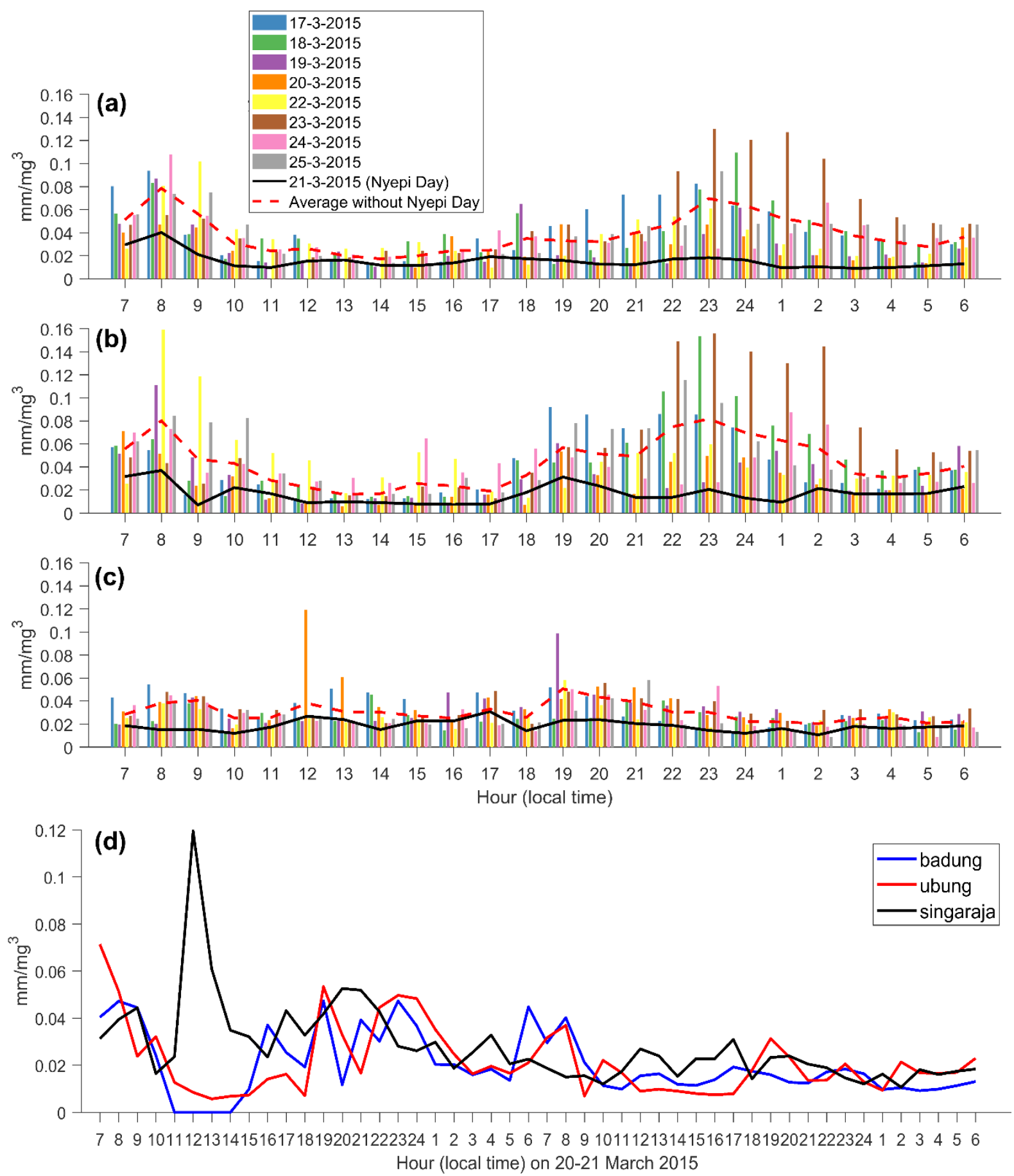

Figure 4. Hourly TSP concentration measured in (a) Badung, (b) Ubung, and (c) Singaraja. Data are plotted in local time. (d) Plot of hourly TSP in the three locations from 20-21 March 2015.

Figure 4 also shows the diurnal cycle of TSP concentration during DOS (black solid lines) and the baseline values (red dashed lines) at the three sites. As is expected, TSP concentrations during DOS were below the baseline values for each hour at all sites. This shows the significant impact of DOS on the TSP concentration in Bali. Interestingly, the TSP concentrations during DOS were relatively constant all day with a small peak at 7-8 AM. This is different to the baseline values in an urban area that have significant peaks at 7-8 AM and between 9 PM-2 AM. Possible causes of this difference could be 
low TSP emissions in the daytime during DOS. During regular days, most TSP was emitted during the daytime as a result of human activities; however, most TSP ascends to the upper air due to atmospheric turbulence and convection, hence there is no TSP peak at the surface. During the night, the surface is cooler, which stabilizes the atmosphere. This causes TSP to descend from the upper air and increases the TSP concentration at the surface. This result is supported by the baseline hourly wind speed values that indicate an increase in wind speed between 9 AM and 7 PM with a peak at $1 \mathrm{PM}$ and lower wind speeds from night to early morning (not shown). During DOS, there was no significant TSP emission to the upper air during the daytime, leading to no TSP peaks during the night. As for the small TSP concentration peak at 7-8 AM during DOS, this may be caused by the influences of TSP concentration from hours prior to DOS (Figure $4 \mathrm{~d}$ ). The relative changes of hourly TSP concentration during DOS and the baseline values are shown in Figure 5. The maximum decreases in hourly TSP concentrations during DOS are 0.054 $\mathrm{mg} / \mathrm{m}^{3}$ at $11 \mathrm{PM}, 0.065 \mathrm{mg} / \mathrm{m}^{3}$ at $10 \mathrm{PM}$ and $0.028 \mathrm{mg} / \mathrm{m}^{3}$ at $7 \mathrm{PM}$ in Badung, Ubung and Singaraja, respectively. It is clear that the largest declines in TSP concentration were observed in urban areas such as Badung and Ubung. This result was also supported by the relative percentage decrease in TSP, which considered the non-anthropogenic background value (Figure 5). In Badung and Ubung (urban areas), the relative percentage decrease in TSP was $78 \%$ and $73 \%$, respectively. Meanwhile, in Singaraja (suburban area), the percentage decrease was $59 \%$. Nevertheless, the TSP concentrations in all three sites were still lower than the threshold allowed by Indonesian Government Regulation No 41, i.e. 0.23 $\mathrm{mg} / \mathrm{m}^{3}$. This result is in agreement with a previous study which investigated the TSP concentrations of the following locations: industrial transportation/vehicular area, rural area, low-density residential area, and high-density residential area. The study found that the rural site had the lowest mean TSP concentration, while the vehicular source site recorded the highest mean TSP concentration (Ikamaise et al., 2013).

Overall, this study shows that during DOS the air quality in Bali was improved in terms of PM due to the decrease in TSP concentration. In other regions, programs with a similar function to DOS have been conducted to improve local air quality. For example, the car-free day is a program that is commonly applied on the main roads in big cities, such as the capital city of Jakarta, where it is forbidden to drive on certain roads during particular times on a specific day, mostly on weekends. However, this program succeeds only in reducing the concentration of gaseous pollutants, but does not have a significant impact on the TSP concentration. It is noteworthy that PM from traffic emission is not the main contributor to the total PM concentration, so car-free days may not cause the total PM concentration to decrease significantly (Vanderstraeten et al., 2010; Masiol et al., 2014). Other human activities such as wood-burning and industrial processes contribute more to TSP concentrations. In addition, wind is also an important natural factor controlling the TSP concentration. DOS restricts human activities with the conditions of no fires/ lights (including electricity), no working, no traveling, and no self-entertainment. While the holiday is seen as the day of selfreflection, the restrictions during the holiday surely affect the environment. DOS does not only improve air quality related to human activities but also improves the audibility of the fish chorus used in mating (Williams et al., 2018). 

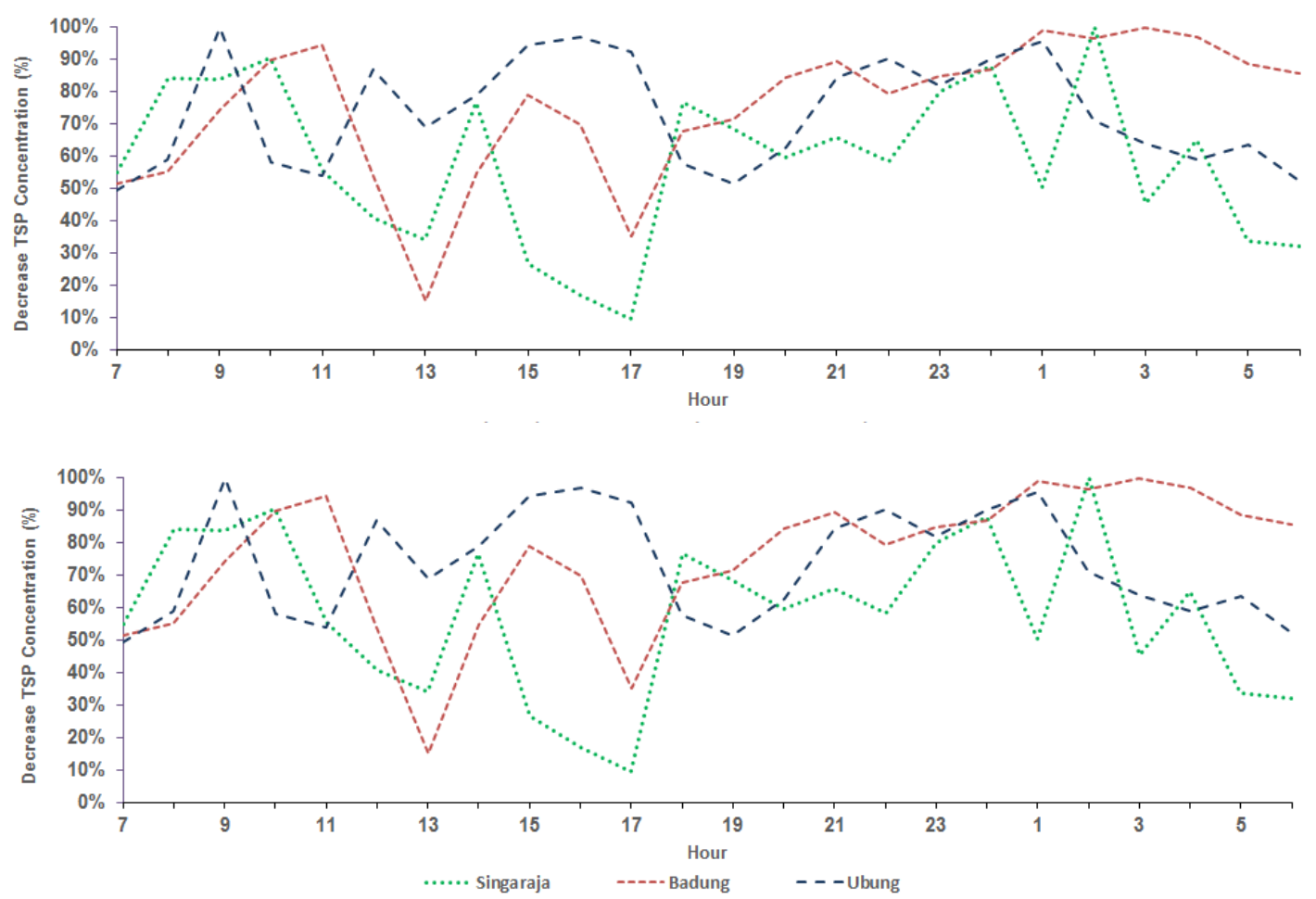

Figure 5. Hourly TSP concentration changes during DOS relative to baseline values (relative changes) measured in (a) milligrams per cubic meter and (b) percentage.

\section{Conclusion}

TSP concentrations and meteorological data were monitored in urban and suburban areas in Bali before, during and after DOS 2015. Temperature and wind speed are meteorological factors that have significant negative correlations with the TSP concentration on a diurnal timescale in each location. TSP concentrations during DOS are lower than the average TSP concentrations before and after DOS, with much more significant decreases in TSP concentration being observed in urban areas located in southern Bali (73-78\%) than in suburban areas in northern Bali (59\%). This indicates that the air quality in Bali was improved, particularly in terms of particle pollutants, during DOS due to the decrease in TSP concentration both in urban and suburban areas. The practice of DOS is only observed in Bali, but other regions might undertake a program or an approach for air quality improvement. One of the approaches that is commonly adopted is a car-free day where it is forbidden to drive on certain roads during particular times on a specific day, mostly on weekends. Unlike DOS, studies show that car-free days do not reduce the TSP concentration significantly but do succeed in lowering the gaseous pollutant concentration because the traffic emission consists mainly of gaseous pollutants. Overall, these results show that human activities do affect TSP concentrations particularly and air quality generally.

\section{Acknowledgements}

The authors thank all parties who have supported this research since the preparation stage, setting the instruments up, and monitoring whether the instruments were working properly. The authors also convey sincere appreciation to their colleagues in the Research and Development Division for Climatology and Air Quality. 


\section{References}

Aldrian, E., Kurniawan, E., \& Kusumaningtyas, S. D. A. (2014). Layanan Kualitas Udara dari Hujan Asam hingga Gas Rumah Kaca. Jakarta: Penerbit Puslitbang BMKG.

Aprilina, K., Badriah, I. U., \& Aldrian, E. (2016). Hubungan antara Konsentrasi Karbon Monoksida (CO) dan Suhu Udara terhadap Intervensi Anthropogenik (Studi Kasus Nyepi Tahun 2015 di Provinsi Bali). Jurnal Meteorologi dan Geofisika, 17(1).

Alias, M., Hamzah, Z., \& Kenn, L. S. (2007). PM10 and Total suspended particulates (TSP) measurements in various power stations. The Malaysian Journal of Analytical Sciences, 11(1), 255261.

Bacon, S. N., McDonald, E. V., Amit, R., Enzel, Y., \& Crouvi, O. (2011). Total suspended particulate matter emissions at high friction velocities from desert landforms. J. Geophys. Res, 116, F03019.

Cohen, A. J., Ross Anderson, H., Ostro, B., Pandey, K. D., Krzyzanowski, M., Künzli, N., ... \& Smith, K. (2005). The global burden of disease due to outdoor air pollution. Journal of Toxicology and Environmental Health, Part A, 68(13-14), 1301-1307.

Colls, J. (2002). Air Pollution, Second Edition, Spon Press, London.

Environmental Devices Corporation USA. (1999), User's Guide Haz-Dust Environmental Particulate Air Monitor Model EPAM 5000, USA

Hrdličková, Z., Michalek, J., Kolář, M., \& Veselý, V. (2008). Identification of factors affecting air pollution by dust aerosol PM 10 in Brno City, Czech Republic. Atmos Environ, 42(37), pp. 8661-8673

Ikamaise, V. C., Akpan, I. O., Essiet, A. A., \& Uwah, I. E. (2013). Concentrations and Source Apportionment of Total Suspended Particulate Matter in Calabar Air Basin. International Journal of Development and Sustainability, 2(2), 1203-1213.

Kasa, I. W. (2011). Local wisdom in relation to climate change. JISSAAS, 17, pp. 22-27.

Kiss, G., Makra, L., Mika, J., Borsos, E., \& Motika, G. (2005). Temporal characteristics of air pollutant concentrations in Szeged, Hungary. Acta Climatologica et Chrologica Universitatis Szegediensis, 38, 39 .

Li, K. H., Le, N. D., Sun, L., \& Zidek, J. V. (1999). Spatial-temporal models for ambient hourly PM10 in Vancouver. Environmetrics, 10(3), pp. 321-338.

Liu, Y. J., Zhang, T. T., Liu, Q. Y., Zhang, R. J., Sun, Z. Q., \& Zhang, M. G. (2014). Seasonal variation of physical and chemical properties in TSP, PM10 and PM2. 5 at a roadside site in Beijing and their influence on atmospheric visibility. Aerosol Air Qual. Res, 14(3), pp. 954-969.

Masiol, M., Agostinelli, C., Formenton, G., Tarabotti, E., \& Pavoni, B. (2014). Thirteen years of air pollution hourly monitoring in a large city: potential sources, trends, cycles and effects of car-free days. Science of the Total Environment, 494, pp.84-96.

Mogere, L. O. (2002). Determination of Concentration of Total Suspended Particulate Matter and some gaseous air pollutants in Athi river urban area, in kenya. Kenya. MSc. Thesis. The University of Nairobi, Nairobi, Kenya.

Oke, T. R. (1987). Boundary layer climates, 2nd (ed.) Routledge. London and Wiley, New York.

Pope III, C. A., \& Dockery, D. W. (2006). Health effects of fine particulate air pollution: lines that connect. Journal of the air $\mathcal{E}$ waste management association, 56(6), 709-742.

Sheng, X. (2004). Boundary layer meteorology and methodology of dispersion modelling. Ad- 
vanced Air Quality Management Training Workshop. Cambridge Environmental Research Consultan.

Sugiarti (2009), Gas Pencemar Udara dan Pengaruhnya Bagi Kesehatan Manusia, Jurnal Chemica periode Juni, Vol.10 Nomor 1

Turyanti, A., June, T., Aldrian, E., \& Noor, E. (2016), Analisis Pola Dispersi Partikulat dan Sulfuroksida Menggunakan Model WRFChem di Sekitar Wilayah Industri Tangerang dan Jakarta. J. Manusia dan Lingkungan, Vol.23 No 2 Juli 2016, pp.169-178

Vanderstraeten, P., Forton, M., Lénelle, Y., Meurrens, A., Carati, D., Brenig, L., ... \& Zaady, E. (2010). Elevated PM10 concentrations and high PM2. 5/PM10 ratio in the Brussels Urban Area during the 2006 car-free Sunday. International Journal of Environment and Waste Management, 6(3-4), pp.264-279

Wardhana, W. A. (1984), Teknik analisis Radioaktifitas Lingkungan. Andi Offset, Yogyakarta.

Williams, R., Erbe, C., Dewantama, I. M. I., \& Hendrawan, I. G. (2018). Effect on ocean noise: Nyepi, a Balinese day of silence. Oceanography, 31(2), pp.16-18

World Health Organization (WHO). (2006). WHO Air quality guidelines for particulate matter, ozone, nitrogen dioxide and sulfur dioxide: Global Update 2005. Summary of Risk Assessment. WHO, Geneva.

Yang, S., Chen, B., \& Fath, B. (2015). Trans-boundary total suspended particulate matter (TSPM) in urban ecosystems. Ecol Model, 318, 59-63 